\title{
PEMBELAJARAN MEMBACA CERITA ANAK DENGAN STRATEGI PEMETAAN CERITA RUMPANG PADA SISWA KELAS V SD NEGERI 103 PALEMBANG
}

\author{
Hayatun Nufus \\ hayatunnufus@univpgri-ac.id
}

\begin{abstract}
ABSTRAK
Masalah dalam penelitian ini adalah bagaimanakah strategi pemetaan cerita rumpang dapat meningkatkan keterampilan membaca cerita anak pada siswa kelas V SD Negeri 103 Palembang. Penelitian ini bertujuan untuk mengetahui dan mendeskripsikan peningkatan keterampilan membaca siswa kelas V SD Negeri 103 Palembang melalui pembelajaran membaca cerita anak dengan strategi pemetaan cerita rumpang. Penelitian ini menggunakan metode penelitian tindakan (action research).Subjek penelitian ini adalah siswa kelas VA SD Negeri 103 Palembang berjumlah 32 siswa.Teknik pengumpulan data yang digunakan pada penelitian ini adalah teknik tes, angket, dan observasi. Berdasarkan pembahasan yang dilakukan, pelaksanaan pembelajaran dengan menggunakan strategi pemetaan cerita rumpang pada materi pembelajaran membaca cerita anak siswa kelas V SD Negeri 103 Palembang, telah terlaksana dengan baik. Penggunaan strategi pemetaan cerita rumpang pada pembelajaran Bahasa Indonesia pada kompetensi pembelajaran membaca cerita anak dapat membantu siswa dalam mengembangkan imajinasinya serta meningkatkan keterampilan membaca cerita anak, hal ini dapat dilihat dari hasil tes pembelajaranmembaca cerita anak, baik dari prasiklus sampai siklus II. Persentase jumlah siswa yang tuntas pada saat prasiklus adalah 12 siswa atau 37,5\%. Dengan nilai rata-rata 68,43. Setelah dilakukan tindakan pada siklus I, meningkat menjadi 20 siswa atau 62,5\% dengan nilai rata-rata 70,31. Kemudian pada siklus II jumlah siswa yang tuntas meningkat menjadi 28 siswa atau 87,5\% dengan nilai rata-rata 78,75.
\end{abstract}

Kata kunci: membaca, cerita anak, strategi pemetaan cerita rumpang

\section{EARNING TO READ CHILDREN'S STORIES WITH MASSAGE STORY MAPPING STRATEGIES IN CLASS V STUDENTS STATE 103 STATE ELEMENTARY SCHOOL, PALEMBANG}

\begin{abstract}
The problem in this study is how the strategy of mapping the overlapping story can improve children's story reading skills in class V students of SD Negeri 103 Palembang. This study aims to find out and describe the improvement in reading skills of fifth grade students at the SD Negeri 103 Palembang through learning to read children's stories with a strategy of mapping up stories. This study uses action research methods. The subjects of this study were students of VA class Palembang SD Negeri 103 totaling 32 students. Data collection techniques used in this study were test techniques, questionnaires, and observations. Based on the discussion carried out, the implementation of learning by using the strategy of mapping the overlapping stories on learning material to read
\end{abstract}


stories of children of fifth grade students of SD Negeri 103 Palembang, has been well implemented. The use of overlapping story mapping strategies in Indonesian language learning on children's learning competence in reading stories can help students develop their imagination and improve children's story reading skills, this can be seen from the results of learning tests reading children's stories, both from pre-cycle to cycle II. The percentage of students who complete at pre-cycle is 12 students or 37.5\%. With an average value of 68.43. After taking action in the first cycle, it increased to 20 students or $62.5 \%$ with an average value of 70.31 . Then in the second cycle the number of students who completed increased to 28 students or $87.5 \%$ with an average value of 78.75 .

\section{Keywords: reading, children's stories, overlapping story mapping strategies}

\section{A. PENDAHULUAN}

Empat keterampilan berbahasa yaitu menyimak, berbicara, membaca, dan menulis. Keterampilan tersebut dapat dibagi menjadi dua kegiatan yaitu kegiatan produktif yaitu kegiatan yang dilakukan seseorang dalam menghasilkan pesan dari pembicara atau penulis dan reseptif yaitu kegiatan yang dilakukan seseorang dalam menerima pesan dari pembicara atau penulis. Menyimak dan membaca merupakan kegiatan yang reseptif, sedangkan dua aspek lain berbicara dan menulis merupakan kegiatan yang produktif. Melalui membaca, seseorang dengan mudah memperoleh informasi yang dibutuhkan. Hudgson (dikutip Nurhadi, 2010:22) mengatakan membaca adalah suatu proses yang dilakukan serta dipergunakan oleh pembaca untuk memperoleh pesan yang hendak disampaikan penulis melalui kata-kata dalam bahasa tulis.

Proses belajar mengajar yang dilakukan dapat dikatakan hanya mendengarkan informasi yang diberikan oleh guru dan mencatat hal-hal yang dianggap penting tanpa memperoleh pengalaman belajar langsung. Pembelajaran seperti ini kurang baik apabila seorang guru hanya menyampaikan apa yang ada di dalam buku tanpa melakukan variasi strategi pembelajaran dan penggunaan media dalam proses belajar mengajar berlangsung. Ini sangat berpengaruh terhadap hasil belajar yang dimiliki oleh siswa.Hal inilah penyebab kemampuan membaca yang cenderung rendah.

Strategi pemetaan cerita rumpang adalah strategi yang menggunakan grafik atau pengorganisasian untuk membantu siswa menemukan unsur-unsur dari sebuah buku atau cerita. Diharapkan dengan menggunakan strategi pemetaan cerita rumpang dapat mengubah cara belajar dengan melatih keterampilan dan pengetahuan siswa. 
Berdasarkan uraian di atas, peneliti tertarik untuk melakukan penelitian mengenai pembelajaran membaca cerita anak dengan strategi pemetaan cerita rumpang dengan judul "Pembelajaran Membaca Cerita Anak dengan Strategi Pemetaan Cerita Rumpang pada Siswa Kelas V SD Negeri 103 Palembang”.

Rumusan masalah dalam penelitian ini adalah bagaimanakah strategi pemetaan cerita rumpang dapat meningkatkan keterampilan membaca cerita anak pada siswa kelas V SD Negeri 103 Palembang?. Penelitian ini bertujuan untuk mengetahui dan mendeskripsikan peningkatan keterampilan membaca siswa kelas V SD Negeri 103 Palemban gmelalui pembelajaranmembaca cerita anak dengan strategi pemetaan cerita rumpang. Manfaat penelitian

Hasil penelitian ini diharapkan dapat bermanfaat bagi pengajaran bahasa dan sastra Indonesia, siswa, guru, dan peneliti selanjutnya.

1) Bagi pengajaran bahasa dan sastra Indonesia di sekolah,bermanfaat bagi pengajaranbahasadansastraIndonesiadisekolah khususnya para guru dalam usaha memperbaiki pembelajaran 2) Bagi siswa,hasil penelitian ini diharapkan dapat dijadikan sebagai salah satu acuan bagi peningkatan prestasi belajar, dan memotivasi siswa dalam kemampuan membaca cerita anak. 3) Bagi guru hasil penelitian ini dapat dimanfaatkan untuk merancang pembelajaran mengenai kemampuan membaca cerita anak. 4) Bagi peneliti selanjutnya, hasil penelitian ini diharapkan dapat menjadi referensi atau bahan rujukan untuk melaksanakan penelitian yang lebih mendalam.

\section{Keterampilan Membaca}

Hudgson (dikutip Nurhadi, 2010:22) mengatakan membaca adalah suatu proses yang dilakukan serta dipergunakan oleh pembaca untuk memperoleh pesan yang hendak disampaikan penulis melalui kata-kata dalam bahasa tulis. Suatu proses yang menuntut pembaca agar dapat memahami kelompok katayang tertulis merupakan suatu kesatuan dan terlihat dalam suatu pandangan sekilas, dan makna kata-kata itu dapat diketahui secara tepat. Apabila hal ini dapat terpenuhi maka pesan yang tersurat dan yang tersirat dapat dipahami sehingga proses membaca sudah terlaksana dengan baik. Seseorang yang sedang membaca berarti ia sedang melakukan suatu kegiatan dalam bentuk berkomunikasi dengan diri sendiri melalui lambang tertulis. 
Makna bacaan tidak tidak terletak pada bahan tertulis saja, tetapi juga terletak pada pikiran pembaca itu sendiri. Dengan demikian, makna bacaan bisa berubah-ubah tergantung pembaca dan pengalaman berbeda yang dimilikinya pada waktu membaca dan dipergunakannya untuk menafsirkan kata-kata tulis tersebut. Nurhadi (2010:13) mengemukakan bahwa dalam membaca terlibat berbagai aspek-aspek berpikir seperti mengingat, memahami, membedakan, membandingkan, menemukan, dan menganalisis. Aspek-aspek tersebut mempengaruhi kemampuan membaca seseorang.

Santoso (2008:46) mengemukakan membaca adalah melihat dan menghayati apa yang tertulis. Dengan sendirinya, kebiasaan-kebiasaan membaca akan membuka cakrawala berpikir dalam menghadapi suatu masalah. Dalam membaca, diharapkan pembaca memahami apa yang dibaca sehingga tujuan yang ditetapkan dapat tercapai dengan baik.

Dari beberapa pendapat di atas, dapat peneliti simpulkan bahwa membaca adalah suatu kegiatan memahami dan menghayati isi bacaan sehingga mendapatkan informasi yang benar.

\section{Jenis-Jenis Membaca}

Menurut Tarigan (2008:57) membaca berdasarkan kecepatan dan tujuannya dapat dibagi ke dalam empat jenis, yaitu; membaca kilat (skimming), membaca cepat (speed reading), membaca studi (careful reading), dan membaca reflektif (reflektVe reading).

a) Membaca kilat (skimming), membaca kilat (skimming) merupaka salah satu cara membaca yang lebih mengutamakan penangkapan esensi materi bacaan, tanpa membaca keseluruhan dari materi bacaan tersebut. b) Membaca cepat (speed reading), membaca cepat adalah membaca yang dilakukan dengan kecepatan yang sangat tinggi. c) Membaca studi (careful reading), membaca studi dilakukan untuk memahami, mempelajari, dan meneliti suatu persoalan, kadang-kadang dituntut pula untuk menghadapkannya dalam ingatan. Untuk keperluan ini, membaca harus dilaksanakan dengan kecepatan yang agak rendah. d)Membaca replektif (reflektive reading), membaca reflektif adalah membaca untuk menangkap informasi dengan terperinci dan kemudian melahirkannya kembali atau melaksanakannya dengan tepat sesuai dengan keterangan yang diperoleh. Membaca reflektif ini biasanya dipergunakan dalam mencari informasi dengan cepat namun waktu yang dibutuhkan singkat. 


\section{Pengertian Cerita Anak}

Cerita anak tidaklah asing bagi telinga kita. Karakteristik cerita anak tidak berbeda halnya dengan hakikat sastra pada umumnya. Menurut Nurgiyantoro (2010:218) pada hakikatnya sastra adalah citra kehidupan, gambaran kehidupan. Alwi (2011:227) mengemukakan bahwa cerita anak adalah cerita yang menceritakan tentang gambar-gambar dan binatang-binatang maupun manusia dengan lingkungan.

Dalam cerita anak tergambar peristiwa kehidupan karakter tokoh dalam menjalani kehidupan sebagaimana diungkapkan dalam alur cerita.Dengan demikian, cerita anak adalah subjek yang menjadi fokus perhatian, dan hal itu tercermin secara konkret dalam cerita.Nurgiyantoro (2010:35) mengatakan bahwa cerita anak adalah cerita yang di mana anak merupakan subjek yang menjadi fokus perhatian.Tokoh cerita anak boleh siapa saja, namun mesti ada anak-anaknya, dan tokoh anak itu tidak hanya menjadi pusat perhatian, tetapi juga pusat pengisahan.

Penulis menyimpulkan bahwa cerita anak adalah suatu cerita yang berkisah tentang kehidupan anak yang bersubjek adalah anak-anak serta kehidupan yang melingkupinya.

\section{Pengertian Strategi Pemetaan Cerita (Story Mapping Strategy)}

Sebuah pemetaan cerita adalah penggambaran cerita visual dari pengaturan atau urutan peristiwa besar dan tindakan karakter cerita. Prosedur ini memungkinkan siswa untuk menghubungkan peristiwa cerita dan untuk melihat struktur dalam pilihan sastra (Santa, 2013:1). Dengan berbagi interpretasi pribadi dari cerita melalui ilustrasi, siswa meningkatkan pemahaman dan apresiasi mereka terhadap cerita. Peta cerita dapat digunakan sebagai kerangka kerja untuk mendongeng atau menceritakan kembali, dan sebagai garis untuk menulis cerita.

Strategi pemetaan cerita adalah strategi yang menggunakan grafik atau pengorganisasian untuk membantu siswa menemukan unsur-unsur dari sebuah buku atau cerita (Santa, 2013:1). Dengan mengidentifikasi karakter cerita, plot, setting, masalah dan solusi, siswa membaca dengan seksama untuk mempelajari detail. Ada berbagai jenis cerita penyelenggara peta grafis. Fokus yang paling dasar pada awal, tengah, dan akhir cerita. Penyelenggara lebih maju lebih fokus pada sifat plot atau karakter. 


\section{Tujuan Pemanfaatan Strategi Pemetaan Cerita}

Tujuan pemanfaatan pemetaan cerita menurut Santa (2013:1) adalah untuk: (1) meningkatkan kemampuan interpretatif siswa dengan memungkinkan mereka untuk memvisualisasikan karakter cerita, peristiwa dan pengaturan, (2) untuk meningkatkan pemahaman siswa terhadap pilihan dengan mengorganisir peristiwa cerita utama (3) untuk mengembangkan perasaan siswa dari cerita yang akan membantu bercerita, menceritakan kembali dan menuliskan kembali, (4) untuk meningkatkan kesadaran siswa bahwa cerita karakter dan kejadian saling terkait

\section{Langkah-langkah Menggunakan Strategi PemetaanCerita}

Langkah-langkah konkret memanfaatkan pemetaan cerita (Santa, 2013:1) yaitu sebagai berikut.

1) diskusikan dahulu komponen utama atau unsur-unsur intrinsik apa yang ingin dipetakan dari sebuah cerita. 2) menyediakan setiap siswa sebuah peta cerita (dalam bentuk bagan, diagram, atau bentuk lainnya) yang masing kosong dan contoh bagaimana cara menyelesaikannya atau melengkapi peta tersebut. 3) setelah siswa membaca sebuah cerita, mintalah mereka melengkapi peta cerita tersebut ataus setelah membaca mereka harus mengisi setiap bagian yang hilang atau rumpang di dalam soal bahasa Indonesia kelas V.

\section{Tahapan Pemanfaatan Strategi Pemetaan Cerita}

Tahapan pemanfaatan strategi pemetaan cerita menurut Santa (2013:1) adalah sebagai berikut:

1) Mengenalkan pemetaan cerita sebagai aktivitas kolaboratif. 2) Perkenalkan strategi ini menggunakan cerita dengan plot rumit. 3) Doronglah siswa untuk memvisualisasikan karakter, pengaturan dan peristiwa. 4) Diskusikan dan grafik karakter utama dan kejadian cerita. 5) Tinjau bagan, memfokuskan perhatian siswa pada urutan kejadian utama. 6) Tekankan apa yang terjadi pertama, selanjutnya, dan kemudian. . . 7) Siswa menyepakati urutan peristiwa yang didaftar, nomor ini secara berurutan. 8) Individu atau kelompok masingmasing bisa menggambarkan satu peristiwa cerita.9) Tampilan ilustrasi selesai dalam urutan pola atau kerangka dapat digunakan untuk menceritakan kembali cerita. 10) Siswa dapat menceritakan kembali cerita untuk kesenangan mereka sendiri, untukpasangan, untuk sebuah 
kelompok kecil atau kelas.11) Ilustrasi cerita dapat ditampilkan dalam vertikal atau urutan horisontal, dalam pola melingkar atau sebagai jejak berliku bahwa jejak pergerakan karakter.

12) Setelah siswa menjadi akrab dengan prosedur ini, mereka dapat membuat urutan ilustrasi yang memberikan garis besar untuk mendongeng atau menulis cerita asli.

\section{B. METODE PENELITIAN}

Penelitian ini menggunakan metode yang digunakan dalam penelitian ini adalah metode penelitian tindakan (action research) atau sering disebut Penelitian Tindakan kelas (PTK). Menurut Mills (dikutip Mertler, 2014:4)

"Penelitian tindakan didefenisikan sebagai penyelidikan sistematis yang dilakukan oleh para guru, administrator, konselor, atau orang lain dengan satu kepentingan tertentu dalam proses belajar dan mengajar atau lingkungan dengan tujuan mengumpulkan informasi tentang bagaimana sekolah mereka beroperasi, bagaimana mereka mengajar, dan bagaimana siswa mereka belajar"

\section{Tempat Penelitian}

Penelitian ini dilaksanakan di Program Studi Pendidikan Bahasa dan Sastra Indonesia Fakultas Keguruan dan Ilmu Pendidikan Universitas PGRI Palembang .Program studi ini merupakan tempat peneliti melaksanakan tugas sehari-hari.

\section{Subjek Penelitian}

Subjek dalam penelitian ini adalah siswa kelas V SDN 103 Palembang berjumlah 32 siswa.

\section{Teknik Pengumpulan Data}

Kegiatan pengumpulan data merupakan kegiatan yang sangat penting dalam penelitian ini, sebab itulah yang akan diolah sesuai dengan tujuan penelitian yang telah ditetapkan. Teknik pengumpulan data dalam penelitian adalah sebagai berikut.

\subsection{Tes}

Arikunto (2013:46) menyatakan tes adalah serentetan pertanyaan atau latihan serta alat lain yang digunakan untuk mengukur keterampilan, pengetahuan inteligensi, kemampuan atau bakat yang dimiliki oleh individu atau kelompok. Teknik yang digunakan untuk 
mengumpulkan data dalam penelitian ini berupa tes membaca cerita anak. Dalam keperluan membaca cerita anak ini, peneliti dengan bantuan guru kelas $\mathrm{V}$ memberikan petunjuk dan pengarahan kepada murid-murid agar mereka membaca cerita anak dengan baik dan benar, pada saat proses pembelajarannya menggunakan strategi pemetaan cerita rumpang.

\subsection{Observasi}

Pedoman observasi pada penelitian ini ditekankan keaktifan siswa pada pembelajaran membaca cerita anak selama proses pembelajaran berlangsung berdasarkan indikator dan deskriptor yang tampak dengan menggunakan strategi pemetaan cerita rumpang.

\section{Teknik Analisis Data}

Teknik analisis data tes penelitian ini dilakukan berdasarkan langkah-langkah diantaranya sebagai berikut.

1) Menghitung dan menetapkan nilai tes setiap sampel dengan tahap-tahap sebagai berikut.

a. Menghitung nilai tes objektif tiap-tiap subjek dengan rumus: $N 1=\frac{B}{S} \mathrm{X} 100$ (Ramidjo, 1998:23).

Keterangan:

$N 1=$ Nilai tes objektif tiap-tiap sampel

$B$ = Jumlah soal tes objektif yang dijawab benar

$S=$ Jumlah soal tes objektif

\subsection{Teknik Analisis Data Wawancara}

Wawancara penelitian ini dianalisis berdasarkan jawaban guru bahasa Indonesia yang mengajar di Kelas V SDN 103 Palembang Jawaban guru diinterpretasikan, dideskripsikan, disimpulkan, selanjutnya dihubungkan dengan hasil data tes dan angket.

\subsubsection{Teknik Analisis Data Angket}

Analisis data adalah proses mencari dan menyusun secara sistematis data yang diperoleh dari hasil wawancara, catatan lapangan, dan dokumentasi dengan cara mengorganisasikan data ke dalam kategori sehingga mudah dipahami (Sugiyono, 2011:244). Analisis data dalam penelitian ini menggunakan analisis data kualitatif. 


\section{HASIL PENELITIAN DAN PEMBAHASAN}

\section{Hasil Penelitian}

Adapun yang akan disiapkan pada tahap perencanaan yaitu melakukan analisis kurikulum untuk menentukan standar kompetensi dan kompetensi dasar yang akan disampaikan kepada siswa dengan menerapkan penggunaan strategi pemetaan cerita rumpang, membuat rencana pembelajaran (RPP) dengan menerapkan penggunaan strategi pemetaan cerita rumpang, mempersiapkan materi pembelajaran mengenai keterampilan membaca cerita anak agar anak mudah memahami materi yang disampaikan, membuat lembar kerja siswa, menyusun alat evaluasi pembelajaran, dan menyiapkan lembar observasi siswa dan guru untuk melihat bagaimana situasipembelajaran dengan menerapkan penggunaan strategi pemetaan cerita rumpang. Seluruh subjek diberikan tes evaluasi yang sama butir-butirnyatiap soal.

\subsection{Prasiklus}

Sebelum masuk siklus 1, terlebih dahulu dilakukan tes awal terhadap keterampilan siswa kelas V SD Negeri 103 Palembang membaca cerita anak dengan strategi pemetaan cerita rumpang. Tes awal dilakukan pada tanggal 28 September 2015.Peserta tes sebanyak 32 siswa.

Berdasarkan hasil prasiklus atau kondisi awal keterampilan membaca siswa kelas V SD Negeri 103 Palembang melalui pembelajaran membaca cerita anak tahun 2015/2016, terdapat 22 siswa dinyatakan belum tuntas nilainya masih di bawah KKM 70. Siswa yang mendapatkan nilai tuntas di atas KKM 70 sebanyak 12 siswa. Nilai rata-rata prasiklus adalah 68,43. Dari tabel di atas dapat disimpulkan bahwa kondisi awal keterampilan membaca siswa kelas V SD Negeri 103 Palembang melalui pembelajaranmembaca cerita anak belum sesuai dengan (KKM). Agar dalam penelitian ini peneliti mendapatkan hasil sesuai harapan, peneliti melakukan penelitian tindakan kelas.

\subsection{Perencanaan}

Pada tahap perencanaan ini tindakan siklus I dilaksanakan selama 2 kali pertemuan (4 x 35 menit). Waktu yang telah direncanakan untk pertemuan pertama yaitu pada hari Kamis tanggal 1 Oktober 2015 selama 2 jam pelajaran adalah 70 menit, tepatnya pukul 07.30--08.40 WIB. Kemudian untuk pertemuan kedua dilaksanakan pada hari Jumat tanggal 2 Oktober 2015 selama 2 jam pelajaran adalah 70 menit, tepatnya pukul 07.30--08.40 WIB. 


\subsection{Tahap Pelaksanaan Tindakan}

Pada kegiatan inti guru menyimak penjelasan tentang pengertian cerita rumpang. Guru memberikan contoh cerita yang rumpang melalui media gambar yang ditampilkan. Siswa membaca cerita yang rumpang.Siswa melengkapi teks cerita rumpang tersebut dengan kalimat yang tepat secara bersama. Siswa menuliskan kembali cerita rumpang yang telah dilengkapi.Kemudian siswa diminta membacakan kembali teks cerita yang sudah dilengkapi. Guru bertanya jawab tentang hal-hal yang belum diketahui siswa. Guru bersama siswa bertanya jawab meluruskan kesalahan pemahaman, memberikan penguatan dan penyimpulan.

\subsection{Observasi}

Pada tahap ini yang dilakukan peneliti adalah mengevaluasi hasil observasi aktVitas siswa, hasil catatan lapangan saat proses pembelajaran berlangsung, dan hasil tes keterampilan membaca siswa kelas V SD Negeri 103 Palembang melalui pembelajaran membaca cerita anak dengan strategi pemetaan cerita rumpang.

Namun, saat kegiatan menyimpulkan materi pembelajaran, penguasaan kelas, dan pemberian pertanyaan atau kuis guru harus lebih meningkatkan kemampuannya agar lebih baik lagi dapun nilai rata-rata tes adalah 70, 31 .

Berdasarkan hasil nilai siklus I keterampilan membaca siswa kelas V SD Negeri 103 Palembang melalui pembelajaran membaca cerita anak dengan strategi pemetaan cerita rumpang tahun pelajaran 2015/2016, terdapat 12 siswa atau 37,5\% dinyatakan belum tuntas nilainya masih di bawah KKM 70 tuntas diatas KKM 70 sebanyak 18 siswa atau 56,25\% yaitu memperoleh nilai antara 75-85. Nilai rata-rata tes siklus I adalah 70,31. Jika dibandingkan dengan hasil belajar sebelum dilakukan tindakan, hasil belajar siswa mengalami peningkatan yang signifikan. Akan tetapi, hasil tersebut masih belum mencapai ketuntasan klasikal seperti yang telah ditetapkan yaitu $70 \%$.

\subsection{Refleksi}

Kegiatan yang dilakukan pada tahap refleksi adalah mengkaji ulang hasil pelaksanaan siklus I untuk menentukan langkah perbaikan pada siklus II. Kelebihan dan kekurangan pada siklus I dijadikan acuan dalam melaksanakan siklus II. Keberhasilan yang diperoleh pada siklus I berupa adanya peningkatan keterampilan membaca siswa kelas V SD Negeri 103 
Palembang melalui pembelajaran membaca cerita anak dengan strategi pemetaan cerita rumpang yang dilihat dari hasil evaluasi siswa. Hal ini disebabkan oleh aktVitas guru yang telah sesuai dengan rencana pembelajaran.

Refleksi siklus I dilakukan setelah melakukan tindakan siklus I. Adapun hasil refleksi siklus I adalah siswa masih asing dengan startegi pemetaan cerita rumpang, siswa kurang antusias bertanya tentang hasil pelajarannya dan guru kurang memberikan pengawasan dan bimbingan terhadap siswa dalam proses pembelajaran membaca cerita anak dengan strategi pemetaan cerita rumpang.

\subsection{Siklus II}

Siklus II dilaksanakan sesuai dengan hasil refleksi dari kekurangan dan kelebihan pada siklus I. Hal ini dilakukan sebagai usaha perbaikan agar keterampilan membaca siswa kelas V SD Negeri 103 Palembang melalui pembelajaran membaca cerita anak dengan strategi pemetaan cerita rumpang dapat mencapai kriteria ketuntasan minimal klasikal.

\subsection{Perencanaan}

Peneliti bekerja sama dengan guru kelas V ibu Siti Rohana, S.Pd. untuk membicarakan perbaikan-perbaikan pada siklus I dan membahas pokok bahasan yang akan disampaikan pada siklus II, terutama mengenai pembelajaranmembaca cerita anak dengan strategi pemetaan cerita rumpang. Waktu yang telah direncanakan yaitu pada hari Senin tanggal 5 Oktober dan 6 Oktober 2015, tepatnya pukul 07.30 - 08.40 WIB. Peneliti menyusun rencana pelaksanaan pembelajaran (RPP) yang mengacu pada tindakan yang akan dilaksanakan dalam penelitian tindakan kelas sesuai standar kompetensi dan kompetensi dasar.

Pada siklus II siswa akan diberikan tugas mengisi sebuah cerita rumpang "Keluarga Angga". Pada cerita tersebut terdapat lima kata yang dihilangkan, kemudian siswa akan mengisi kata-kata yang hilang dengan kata-kata yang telah disediakan. Berikut lembar tugas siswa pada siklus II.

\subsection{Tahap Pelaksanaan Tindakan}

Pada tahap pelaksanaan tindakan, siswa diminta untuk mengumpulkan hasil tes mereka pada siklus II.Kemudian siswa dengan bimbingan guru membuat kesimpulan dan refleksi dari kegiatan pembelajaran yang dilakukan.Selanjutnya, guru memberikan motivasi agar siswa 
terus berlatih dalam pembelajaranmembaca cerita anak dengan strategi pemetaan cerita rumpang.

\subsection{Observasi}

Hasil analisis tersebut menjelaskan bahwa pencapaian hasil ketuntasan belajar siswa pada pembelajaran membaca siswa kelas V SD Negeri 103 Palembang melalui pembelajaranmembaca cerita anak dengan strategi pemetaan cerita rumpang, di siklus II ini telah mencapai kriteria ketuntasan minimal klasikal yakni 87,5\%. Dengan demikian dapat dikatakan pembelajaran membaca siswa kelas V SD Negeri 103 Palembang melalui pembelajaran membaca cerita anak dengan strategi pemetaan cerita rumpang pada siklus II telah berhasil meningkatkan keterampilan siswa membaca cerita anak.

Siswa yang mendapatkan nilai tuntas di atas KKM 70 sebanyak 28 siswa atau 87,50\% yaitu Nilai rata-rata siklus II adalah 78,75. Jika dibandingkan dengan hasil belajar sebelum dilakukan tindakan, hasil belajar siswa mengalami peningkatan yang signifikan.

\subsection{Refleksi}

Berdasarkan hasil observasi yang dilaksanakan selama proses pelaksanaan tindakan pada siklus II sudah menunjukkan perubahan yang berarti, baik dari pelaksanaan proses pembelajaran dan hasil belajar tentang keterampilan siswa kelas V SD Negeri 103 Palembang melalui pembelajaran membaca cerita anak dengan strategi pemetaan cerita rumpang. Hasil refleksi pada siklus II yaitu (1) pelaksanaan pembelajaran yang dilakukan oleh guru kolaborator sudah mengacu pada RPP. Materi yang disampaikan sesuai yang telah direncanakan, (2) siswa sudah mengerti mengenai pembelajaran membaca cerita anak dengan strategi pemetaan cerita rumpang, (3) guru lebih fokus membimbing siswa dan mengarahkan siswa dalam pembelajaran membaca cerita anak dengan strategi pemetaan cerita rumpang.

Persentase jumlah siswa yang tuntas pada saat prasiklus adalah 12 siswa atau 37,5\%. Dengan nilai rata-rata 68,43. Setelah dilakukan tindakan pada siklus I, meningkat menjadi 20 siswa atau 62,5\% dengan nilai rata-rata 70,31. Kemudian pada siklus II jumlah siswa yang tuntas meningkat menjadi 28 siswa atau 87,5\% dengan nilai rata-rata 78,75.

\section{Pembahasan}

Hasil pengamatan yang diperoleh dari tahap awal observasi pada penelitian ini bahwa keterampilan siswa kelas V SD Negeri 103 Palembang melalui pembelajaran membaca cerita 
anak dengan strategi pemetaan cerita rumpang tergolong masih sangat rendah. Dalam temuan didapati bahwa rendahnya keterampilan siswa dipengaruhi oleh beberapa hal diantaranya kurangnya motivasi belajar dan daya serap belajar individu anak yang kurang, serta rendahnya kepercayaan diri siswa dalam proses. Selain itu juga, penggunaan metode pengajaran masih kurang tepat, pengelolaan kelas yang dilakukan guru masih kurang bervariasi yang tentunya akan mempengaruhi daya serap siswa terhadap pembelajaran menjadi lamban.

Temuan hasil evaluasi pada siklus I menunjukkan bahwa keterampilan siswa kelas V SD Negeri 103 Palembang melalui pembelajaranmembaca cerita anak dengan strategi pemetaan cerita rumpang pengalami perkembangan dibanding hasil observasi awal. Hal ini mengacu pada rekapitulasi hasil observasi yang menunjukkan bahwa dimensi dan aspek penilaian keterampilan siswa kelas V $\quad$ SD Negeri 103 Palembangmelalui pembelajaranmembaca cerita anak dengan strategi pemetaan cerita rumpang berkategori cukup dengan perolehan skor rata-rata 70,31.

Adapun pada siklus II, pembelajaran lebih ditekankan pada perbaikan siklus sebelumnya dengan memperhatikan aspek-aspek yang masih rendah.Kegiatan yang dilakukan pada siklus ini difokuskan pada pemberian motivasi dan dorongan pada siswa agar lebih apresiatif terhadap kegitan pembelajaranmembaca cerita anak dengan strategi pemetaan cerita rumpang sehingga tidak ada tekanan bagi siswa untuk mengikuti pembelajaran.

Hasil evaluasi pada siklus ini memperlihatkan bahwa aspek penilaian keterampilan siswa kelas V SD Negeri 103 Palembangmelalui pembelajaran membaca cerita anak dengan strategi pemetaan cerita rumpang, mengalami peningkatan yang cukup signifikan dibanding siklus sebelumnya. Meskipun salah satu aspek belum mencapai skor tertinggi, namun secara keseluruhan perolehan rata-rata berkategori baik dengan total skor 78,75.

Berdasarkan uraian di atas maka dapat disimpulkan bahwa tindakan pembelajaran membaca cerita anak dengan strategi pemetaan cerita rumpang berhasil meningkatkan keterampilan siswa kelas V SD Negeri 103 Palembang membaca cerita anak. 


\section{D.SIMPULAN}

Penggunaan strategi pemetaan cerita rumpang pada pembelajaran Bahasa Indonesia pada kompetensi pembelajara nmembaca cerita anak dapat membantu siswa dalam mengembangkan imajinasinya serta meningkatkan keterampilan membaca cerita anak, hal tersebut dapat dilihat dari data-data nilai pada siklus 1dan siklus 2. Persentase jumlah siswa yang tuntas pada saat prasiklus adalah 12 siswa atau 37,5\%. Dengan nilai rata-rata 68,43. Setelah dilakukan tindakan pada siklus I, meningkat menjadi 20 siswa atau 62,5\% dengan nilai rata-rata 70,31. Kemudian pada siklus II jumlah siswa yang tuntas meningkat menjadi 28 siswa atau $87,5 \%$ dengan nilai rata-rata 78,75. Ini menunjukkan nilai membaca cerita anak siswa kelas V SD Negeri 103 Palembang mengalami peningkatan yang cukup signifikan.

\section{DAFTAR PUSTAKA}

Alwi, Hasan. 2011. Kamus Besar Bahasa Indonesia. Jakarta: Gramedia Pustaka Utama.

Arikunto, Suharsimi. 2010. Prosedur Penelitian: Suatu Pendekatan Praktik (Edisi Revisi). Jakarta: Rineka Cipta.

Arikunto, Suharsimi. 2013. Dasar-Dasar Evaluasi Pendidikan Edisi 2. Jakarta: Bumi Aksara.

Arikunto, Suharsimi dkk. 2014. Penelitian Tindakan Kelas. Jakarta: Bumi Aksara.

Metler, Craig A. 2014. Penelitian Tindakan Kelas: Meningkatkan Sekolah dan Memberdayakan Pendidik. Jakarta: Indeks.Nurgiyantoro, Burhan. 2010. Teori Pengkajian Fiksi. Yogyakarta: Gadjah Mada University Press.

Nurhadi. 2010. Bagaimana Meningkatkan Kemampuan Membaca Cepat. Malang: Sinar Baru Algasindo.

Nurhadi. 2010. Membaca Cepat dan Efektif. Malang: Sinar Baru Algasindo.

Santa, Christina. 2013. Story Maps Strategy (online) http:// www.readingrockets.org /strategies/story_maps di akses 25 Februari 2015.

Santoso, Elha. 2008. Kamus Praktis Modern Bahasa Indonesia. Surabaya: Pustaka Dua.

Sugiyono.2009. Metode Penelitian Pendekatan Kuantitatif, Kualitatif dan R \& D. Bandung: Alfa Beta.

Tarigan, Henry Guntur. 2008. Membaca Sebagai Suatu Keterampilan Berbahasa. Bandung: Angkasa. 